\title{
On the Playing Fields of the World (and Corsica): Politics, Power, Passion and Polyphony
}

DOI:

10.1080/09681220308567353

\section{Document Version}

Accepted author manuscript

Link to publication record in Manchester Research Explorer

\section{Citation for published version (APA):}

Bithell, C. (2003). On the Playing Fields of the World (and Corsica): Politics, Power, Passion and Polyphony. British Journal of Ethnomusicology (special issue Fieldwork Impact, edited by Timothy Cooley), 12(1), 67-95. https://doi.org/10.1080/09681220308567353

\section{Published in:}

British Journal of Ethnomusicology (special issue Fieldwork Impact, edited by Timothy Cooley)

\section{Citing this paper}

Please note that where the full-text provided on Manchester Research Explorer is the Author Accepted Manuscript or Proof version this may differ from the final Published version. If citing, it is advised that you check and use the publisher's definitive version.

\section{General rights}

Copyright and moral rights for the publications made accessible in the Research Explorer are retained by the authors and/or other copyright owners and it is a condition of accessing publications that users recognise and abide by the legal requirements associated with these rights.

\section{Takedown policy}

If you believe that this document breaches copyright please refer to the University of Manchester's Takedown Procedures [http://man.ac.uk/04Y6Bo] or contact uml.scholarlycommunications@manchester.ac.uk providing relevant details, so we can investigate your claim.

\section{OPEN ACCESS}




\title{
On the playing fields of the world (and Corsica): politics, power, passion and polyphony
}

\author{
Caroline Bithell \\ University of Manchester, UK
}

NOTE: This is a post-print (Author's Accepted Manuscript) for:

Bithell, Caroline, 'On the Playing Fields of the World (and Corsica): Politics, Power, Passion and Polyphony'. In Fieldwork Impact, ed. Timothy Cooley special issue of The British Journal of Ethnomusicology, vol. 12/1 (2003): 67-95. DOI: $10.1080 / 09681220308567353$

In this article I consider issues relating to the impact of the fieldworker on the communities studied, both in the immediate present through our involvement in the field, and retrospectively (notably in cases where our recordings might serve to fuel musical revivals by future generations). In the process I revisit aspects of the post-modern dilemma (representation, repatriation etc.) in the context of my own fieldwork in Corsica, aiming to highlight the particular sensitivities called for in a field where questions of identity and tradition are keenly debated, where musical developments command widespread public attention, where there is an especially close relationship between musical discourse and political activity, and where representations constructed by the players themselves are already well-established. ${ }^{1}$

\section{Introduction: turning the heat on experience}

In the last decades of the 20th century, social and cultural anthropology's postmodern crisis focused in large part on the politics of ethnography, expressing itself in the discipline's overriding concern with the construction of texts, its questioning of ethnographic authority, its contentions of the impossibility of objectivity and its rejection of what was now seen as a false divide between poetics and politics (concerns given perhaps their most heeded expression in Clifford \& Marcus 1983 and

\footnotetext{
${ }^{1}$ This article has grown out of a paper originally presented at the 2000 conference of the British Forum for Ethnomusicology, held at the University of Sheffield. I am grateful to my two anonymous readers for their stimulating comments which have inspired me greatly in fine-tuning this piece for publication.
} 
brilliantly reviewed in Marcus 1998). While these concerns were not entirely new, by the 1990s the "representation" debate firmly occupied centre stage and a statement of one's own stance had become a more or less obligatory ingredient in the introduction to any ethnography. ${ }^{2}$ At the same time, many continued to feel that this emphasis on "the politics of writing ethnography" was not being matched by sufficient concern for "the politics of anthropological practice in the field" (Jaffe, 1993:56; my emphases). It was against this backdrop that the volume Shadows in the field (Barz \& Cooley, 1997) burst onto the scene, with the specific objective to "shift the focus of ... 'crisis' from representation (text) toward experience (fieldwork broadly defined)" and to "consider more meaningfully the aspects of the ethnographic process that position scholars through their fieldwork as social actors within the cultures they study" (:4). This is not to say that issues relating to the impact of conducting fieldwork had to this point been completely ignored. ${ }^{3}$ In volumes devoted to fieldwork experience (as opposed to handbooks on fieldwork methodology), however, the spotlight has tended to focus more on the impact of the experience on the researcher than on the impact of the researcher on those studied. The volume Being an anthropologist: fieldwork in eleven cultures (Spindler, 1970), for example, was devoted to a consideration of the ways in which the fieldworker has to adapt to the host culture and is changed at a personal as well as a professional level by the process of conducting fieldwork and, of necessity, living part of his or her life in a different world. The task of producing an account which seeks to describe and assess the impact of fieldwork in terms of the ways in which the host community might itself be changed - or at least profoundly marked by its encounter with the fieldworker is certainly a more challenging one. The Spindler volume does allude to the way in which "the personal adaptation and involvements of the anthropologist in the field" can be seen to exert a significant influence "on not only the reporting and interpretation of events but upon the events themselves" (1970:vi). The task of isolating and measuring long-term changes that may have occurred as a direct result of the activities of a particular fieldworker or team of researchers is, however, a particularly complex one, not least because any

\footnotetext{
2 In a sense this convention is, of course, simply a matter of situating and elucidating one's "position", both literal and ideological,with respect to those one has interacted with and is now writing about; as such it is part of professional methodology. The point is that (a) the associated issues had become more sensitive, and (b) addressing them was part of a broader process of defining new models and standards for ethnographic practice.

${ }^{3}$ In the UK, the 1989 conference of the Association of Social Anthropologists served as an important focus for the debate and addressed issues relating to the anthropologist as both writer and fieldworker. A number of papers from the conference were subsequently brought together in the volume Anthropology and autobiography (Okely \& Callaway, eds, 1992).
} 
such assessment may in itself involve research by yet another fieldworker who will need to be possessed of a suitably historical overview covering a significant timescale. (And ironically, perhaps, this situation will normally need to be described and analysed in writing if it is to be brought to the attention of an interested scholarly audience.) On the other hand, I would argue that even if observations regarding our own impact on events as they occur are likely to remain at a more anecdotal level this should not invalidate any attempt to theorise such impact.

I would also argue that issues of representation still need to be considered, not least because of the way in which the ghostly presence of any intended written account broods over our time in the field and inevitably informs the manner in which we operate, influencing the practical choices we make and underlying many of the dilemmas which begin to surface long before we ever set pen to paper. Moreover, it hardly needs restating that any ethnography we write has the potential to profoundly affect our reception by our erstwhile friends, collaborators and academic colleagues when we return to the field at a later date and, by extension, that of other researchers who may follow in our footsteps. In the first part of my discussion, therefore, I set out to unravel some of the theoretical, ethical and political questions relating to the issue of representation, whilst at the same time seeking to elucidate the interdependence of the act of representation in writing and the field experience which both precedes and underpins it. My discussion then develops into a more focused exploration of the ways in which our presence in the field may, in its own right, have an impact on both the people and the events with whom we come into contact, either directly or as a consequence of the way in which our presence is interpreted by those among whom we work. Finally, I consider the potential impact of our work on future generations, in particular through our role in the conservation of musical materials.

\section{Ethnomusicological fieldwork in the age of globalisation: a brief swot analysis}

In terms of both what and how we study, a particular challenge faces the ethnomusicologist as a result of the increased speed at which acculturation now takes place and the very tangible effects of globalisation on musical activity. ${ }^{4}$ There is a pull exerted on musics, as never before, from periphery towards centre with all

\footnotetext{
${ }^{4}$ For readers unfamiliar with the world of business plans, market analysis and bids for lottery funding, SWOT stands for Strengths, Weaknesses, Opportunities and Threats.
} 
of the power politics that this implies. Local or indigenous musical languages are more than ever vulnerable, or open, to the influence of other sounds - largely but not only 'western' - which fill the air waves in ever more remote corners of the globe. As a result, few of us can maintain the illusion that the fields in which we work are unmuddied - or unfertilised - by outside influences, technological acumen or market forces. New strategies are required for handling musical activity which we can no longer see as operating as a closed system, either in strictly musical terms or with respect to its point of reference, the musicians with whom we now work often having forged explicit and highly visible links with outside audiences, whether it be through involvement with the local tourist industry or in the form of making recordings for world music labels and accepting invitations to perform abroad. ${ }^{5}$

I am not suggesting that the fields of the past - the hidden clearings in impenetrable jungles whose scantily clad inhabitants would start at the sound of their own voices issuing from a magic black box - should be mourned as part of a lost golden age of innocence and purity. The prospect of studying change at the rate at which it often proceeds today is an eminently exciting one, as is the opportunity to witness the ways in which people negotiate paths and strategies which allow their musics to find the new meanings and functions necessary for their survival in a very different kind of world.

In the type of field in which we might now work, however, it is often neither easy nor sufficient to focus on the musical document alone. Erlmann summarises the latter-day view that "meaning does not reside in the music ... but is essentially produced in the ever-shifting interaction between actors, interpreters, and performers" (1996:102) and, in his discussion of analysis, proposes that "musical analysis ... seeks to uncover the processes by means of which certain people - socially situated and culturally determined actors - invest certain sounds with meanings" (:49). I realise that I am blithely bypassing at this point a veritable labyrinth of debate, the complexities of which lie far beyond the scope of the present discussion. If we give credence nonetheless to this qualification of our enterprise, it follows that we need to know exactly who these certain people are, how they are situated socially and in what way they are determined culturally. It also follows that, as the actors, interpreters and performers change, or as the conditions of their lives change, so the meaning changes. The happy side to all this is that there is no danger of our sources

\footnotetext{
${ }^{5}$ These trends are admittedly not entirely new - we have hopefully long since relinquished the idea of a status quo where cultural expression is concerned - but the point is that in "modern" times the
} 
drying up: there will always be something for us to investigate and write about. The downside is the increasingly complex and sometimes sensitive nature of the task facing us as we try to fit all the pieces into place.

\section{Representation and self-representation: meanings and motives}

If we are now used to worrying that in our ethnographic texts we are to some extent inventing, rather than merely representing, the cultures we write about (Clifford, 1986:2), so we must also be aware of the ways in which those we study are to some extent reinventing their own cultures as musicians and others begin to play a more active role in shaping and promoting their traditions for outside consumption. In the context of "internationalisation", Meintjes refers to the stance whereby expressive culture is viewed as "part of a gigantic complex system of trafficking of sounds and signs that are presentations to the outside world of the collectivity's identity in the form of commodities" (1990:63-4). In our media-fuelled age with its ever more widespread fascination with, and consumption of, "other" cultures, those who belong to those cultures not only have a vested interest in how they are represented by outsiders (ourselves included): they are often actively engaged in the construction of their own self-representation with which our representations might conflict. Meanings are no longer neatly contained in local contexts (if indeed they ever were). The market itself introduces the need for a strategy; it offers an invitation to tell the story in a certain way. Hence in a world where those variously referred to as "folk", "ethnic" or "roots" musicians are increasingly talking and writing about their own "traditions" (via press releases, festival brochures, web sites and the like), we might do well to keep open minds here, too, about how universally "real" some realities actually are; to listen for the sub-themes of the stories, search for the hidden complications of the plot. A certain rhetorical masking can become part of the art form as stress is typically placed on the music's traditional roots, its present exponents almost inevitably being presented as its most authentic interpreters who hail from the oldest families, the most traditional villages - depictions that in reality might tell us more about marketing strategies than about how the musicians concerned actually see their position within their own community. At the same time, like the heroes of national football teams, the stars of the world music market come to occupy in the international public eye an iconic Eden, a million miles away from 
the favela, the barrio or the bergerie. Most of those who buy world music CDs are unlikely to go and see for themselves - even if, in the age of The Rough Guide, Andy Kershaw and co., musical tourism is doubtless on the increase. ${ }^{6}$ As ethnomusicologists, we can and should. A vital part of our role is surely to be the tellers of the stories behind the music which will lead to a more informed listening experience and deeper intercultural understanding. At a less lofty level, it may be a matter of lending perspective to aesthetic appreciation. To take an example, recent Corsican output of "traditional" material on CD features all manner of different approaches with their own artistic agendas. Many discs, by their nature, are a product of careful arrangement and rehearsal. As musicians come to view themselves more as individual artists than as faceless representatives of an unchanging tradition and to engage with the question "what constitutes the tradition of today?", the approach inevitably becomes more creative with material often being subject to quite unusual styles of interpretation. ${ }^{7}$ Some discs represent a record of an experimental fusion project that was by its nature transitory, particularly if it relied heavily on improvisation. It is possible to trace an individual song - a lament, say through a series of quite different incarnations. This is utterly fascinating in its own right, but it would be bizarre if a listener were to take any one of these "records" as indicative of the way in which a lament would be sung in context. Insiders already have a framework within which to place any new interpretation: they know what they are listening to, and they might judge the results to be "good" or otherwise according to a whole range of often complex criteria. Outsiders can only take what they hear at face value.

Nor is the phenomenon of fusion restricted to the musical fabric alone. Loizos has spoken of some of those we study as falling into the category of "ordinary people [taken] out of themselves (and out of their communities) and [offered] ... a metalanguage" by the "distancing devices" of "anthropological discourses" (1992:172). In my own encounters with semi-professional performers on their way to becoming world travellers on the strength of their musical passport, I have been struck by the

\footnotetext{
${ }^{6}$ Most readers in the UK will be familiar with Andy Kershaw's radio programmes on roots and world music and with his regular appearances on Lucy Duran's weekly World Routes programme on Radio 3. There was much lamenting at the demise of an earlier series which took the form of a half hour weekly broadcast featuring a more in-depth analysis of a culture area or genre, often by one or other of one's ethnomusicological colleagues.

${ }^{7}$ I have discussed elsewhere (Bithell 1996) the treatment of traditional material in commercial discs and the transformations in musical and paramusical detail that can occur as musicians adapt to the conditions, possibilities and conventions of the new medium while also consciously shaping a sound which will correspond to what they perceive to be the values and expectations of their new audience.
} 
way in which they have acquired elements of a recognisable discourse of musical "roots" through their involvement in the festival and concert tour circuit (as well as, in some cases, through their own involvement in the academic world). Whilst such discourses might, to quote Loizos again, offer "a plurality of ways of thinking about the world which are not confined to what is locally produced, or 'home-grown'" (ibid), they also offer a way of presenting culture which is to a greater or lesser degree generalised rather than being derived from the specific circumstances of any one particular culture. The entry of musicians into the international performance circuit means that they are well-placed to act as bridges - in all manner of ways between highly localised village practices and perspectives and those of "Europe", "the West" or even "the world" as a whole. In the context of self-representation, such observations alert us to the need to look outside in order to understand what is going on inside the cultures we study. As I have argued above, we need more than ever to be intimate with local histories and defining moments that have helped to shape the world view of those we seek to understand, but we also need to know where else they have been, both literally and metaphorically.

The increased vested interest by the "actors" themselves in the way in which their cultures and traditions are represented inevitably impinges on our own writing projects. While in the past it was more often than not safe to assume a clear distinction between the people we wrote about and the people we wrote for, we are now used to the idea that some of our subjects, at least, are likely to feature among our readers. ${ }^{8}$ The papers brought together in the volume When they read what we write (Brettell, 1993) specifically address this issue, throwing up many a salutary tale in the process. A number of the contributions specifically explore the way in which future fieldwork is affected after the publication of an ethnographic text which has upset, angered or scandalised those whose trust the fieldworker had previously enjoyed but was later considered to have betrayed. For those of us alerted to such cautionary tales, the prospective reception of the ethnography that we will later write inevitably constitutes an important part of a broader portfolio of ethical concerns which also inform the manner in which we operate in the field and, in particular, the way in which we relate - from the very outset - to the people we now hesitate to call our "subjects" or "informants".

\footnotetext{
${ }^{8}$ This prospect had been raised long before it became a central issue. Watson (1999:21) cites Gluckman's remarks (1967:xviii) about "tribal people" being "eager to read what is being said about themselves" and "likely to protest if they think that they are being misrepresented".
} 
As Brettell observes (:3), the issue of "native" reception becomes more critical the nearer the field to home, since it is here that the "insiders" are most likely to fulfil the necessary prerequisites of both understanding the language we write in and being literate. In my own case I was, right from the start, in no doubt that many of those with whom I had worked in Corsica would be desperate to see any text I might produce as soon as it was off the press - several "orders" were placed for copies of my thesis (Bithell, 1997) - and I knew that they would scour it for references to themselves and others to see what I had said about them, just as I had seen them scour Laade's German text (1981) with me on hand to translate. ${ }^{9}$ Few Corsicans as yet understand English; it will no doubt be the international players - those with the strongest vested interest in what is said and written about their music - who will be among the first to decipher my text.

As Pitt-Rivers (1992:136-7) has pointed out, however, an ethnographic text which addresses issues of significance to the ethnographer and to his readers in his own time may have little relevance to readers in other times and places who ask different questions and hold different assumptions which inevitably colour their interpretation of the data. The ethnographer, consciously or otherwise, "reads" the culture he studies in the light of current hypotheses and preoccupations with their own specific terminology which has often been endowed with new specialised meanings. Where in one age we might have looked for social facts and cultural norms, in the next we might look for fluid boundaries, liminal spaces and contested identities. We write, as well as read, one text against another. We speak a language of our own, drawing on notions of icons and signifiers which will inevitably remain a mystery to the uninitiated. ${ }^{10}$

Even if they are conversant with the academic discourse, little of this is likely to be of central relevance to those we write about. Their concerns with regard to their own culture are likely to be more immediate, more tangible; the broader view lacks urgency. We might well appear, from their perspective, to be foregrounding or exaggerating certain issues and sidelining or ignoring others, consistent with the particular debate with which we wish to engage. Our account may appear unbalanced, a misrepresentation; it may suggest that we have missed the point, that

\footnotetext{
9 The publication of the text in French translation was being awaited with a certain impatience.

${ }^{10}$ Our text may - like the present article - have started life as a conference paper, responding to a specific agenda, later to be reincarnated as a contribution to an edited volume with its own particular slant on the theme. It is difficult to know whether or not I would have written this same article
} 
we have failed to understand. They might feel that their efforts to contribute to our study have been a waste of time, that they have missed an opportunity to make their voice heard through us. They may understandably be unaware that we may have entered the field seeking answers to specific questions which would not, in any case, correspond to their idea of the most interesting, important or urgent questions. Even if we try to explain what we are looking for, there is no guarantee that either the local interpretation of our explanation or the local understanding of how we might best set about achieving our stated objective will match our own intended meaning. McKechnie (1993), for example, reports how during her fieldwork in Corsica in which she set out to investigate notions of identity - what it means to be Corsican people constantly tried to direct her towards supposedly "real" Corsicans in the form of self-styled traditional folk who dressed in pseudo-traditional garb and artisans pursuing traditional rural crafts, while chiding her for wasting her time gossiping in the local cafes.

It is, however, not just these broader perspectives that are lacking at the local or insider level, but more pertinently an intimation of "where we are coming from", not only in terms of the nature of academic debate current in the discipline as a whole but also in terms of the circumstances in our own cultures that might have inspired us to study theirs in the first place. (I refer to Pitt-Rivers' proposal (1992:137) that "all fieldwork responds to a problem, originating in the fieldworker's own society".) And if fieldwork is more art than science, then of course we will each paint our picture in different shades, layer our images in a different order. We are not, in any case, searching for immutable facts.

All things considered, then, we are unlikely to produce the texts our informants would like us to write. Moreover, if we try consciously to do this, the text that results might not pass the scrutiny of academic reviewers back home which is necessary to allow it to reach the point of publication. This was brought home to me on one occasion when a paper on which I had expended considerable time and effort did not receive favourable reviews. It was only in retrospect that I realised the extent to which I had been concerned to write something that would please a Corsican audience, something that they would see as promoting a cause close to their hearts, something whose authorship I would have no qualms in admitting to. In the process I had omitted to problematise the issues sufficiently for an Anglo-American

without the initial stimulation and subsequent encouragement (not to mention the exacting deadlines). 
readership; I had failed to relate my analysis closely enough to current debates and methodologies; my text was out of sync with the academic times - as indeed would be many of my Corsican readers who would not have read all the latest journal articles and ethnographies hot off the North American university presses. I had made the mistake of writing in a time and space where I had imagined I might meet them on their home ground. From the point of view of my relationship with my Corsican friends and informants, the failed article represented a missed opportunity which would have benefited us both - them by putting some of their concerns more firmly on the map and myself by having allowed me to "give back" what I had hoped would be grist to their mill and a more solid token of my best intentions, a clear signal that we were playing on the same side.

\section{Choices and sensitivities}

In my own research into polyphonic singing in Corsica, people often seemed most interested in questions of origins. Where did the paghjella (the most typical style of Corsican polyphonic song) come from? When did it originate? What form did it originally take? When were the different voices added? It was these historical questions to which scientific answers were sought. At the same time, I would be told that ethnomusicologists had come and gone before me but they had added nothing to what was "known" already and it was likely that I, too, would go away having failed to discover anything new. Others would simply assert that there was nothing new to discover: it had all been done already. Any idea that I might be looking for answers to very different questions was a long way from most people's understanding of the types of questions that might be asked about musical performance or repertories.

While questions relating to the evolution of Corsica's characteristic style of polyphonic singing did indeed fascinate me, my interest did not begin and end with the musical "document" alone. From the outset I was on the trail of the intriguing story of the near miraculous resurrection of a traditional music culture which, in the early 1970s, had supposedly been close to drawing its last breath. The more I talked to people, the more multifaceted the story became. I was at the same time humbled and excited by the powerful passions expressed by many of those involved; I found the political ramifications (of which more below) strangely seductive; above all, my 
intellectual taste-buds were stimulated by the vitality and urgency of the theoretical debates.

Not surprisingly, when I came to write up my research I found myself embroiled in all manner of potentially controversial areas. I had worked with many of the older singers and attended a wide range of traditional events such as sheepshearing parties, shepherds' fairs, and masses sung for patron saints on mountain tops and in olive groves. I had spent whole weeks at a time in archives transcribing and analysing historical field recordings. I had considered questions of origins and evolution. But I had also conducted interviews with members of most of the contemporary groups, had attended their concerts, bought their CDs, and followed their legendary progress via reviews and press reports. I had been party to many permutations of the often intense debates concerning tradition and authenticity, tradition and creation, tradition and contemporaneity. ${ }^{11}$ I was aware of certain tensions between young aspiring group members and older village singers, of the misgivings of some onlookers as they observed the passage of the music from a local, "ethnic" frame of reference to an international performance context, of the resistance to an appropriation of cultural capital by a supposed elite in the service of their own artistic or political agendas. In my weaker moments I considered writing an account which focused more on the music and less on the musicians, more on the past and less on the present, an account which would keep me on dry land and out of harm's way - but I knew that the results would be comparatively bland, that a wealth of fascinating material would thereby go to waste, and that unfortunately the approach as a whole would have to be viewed by myself, even if not by anyone else, as somewhat cowardly. What interested and intrigued me, and indeed seemed to offer significant potential in terms of meaningful academic debate, was the story of the revival and the somewhat unlikely reversal in fate that it had occasioned - a story that would inevitably feature personalities, projects, reactions, repercussions, not to mention the powerful passions behind all of these - and, of course, politics.

The high status of, and intense interest taken in, musical activity in Corsica today reinforced the need for sensitivity. Polyphonic singing in particular is well on the way to being a national obsession. In activist circles, singing paghjelle had come to function not only as a means of rediscovering one's musical roots and recreating the sense of community which had existed among village men in the past but also as an 
important focus for nurturing team spirit in the context of the present struggle. By the mid-1990s, the island's characteristic polyphonic style had established itself as a sophisticated and revelatory presence on the world music map and was now being cultivated as an art in its own right. These days, while Brazil might export football, Corsica exports polyphony; while small boys in the favela might dream of playing in the World Cup final, their Corsican counterparts dream of singing with Canta or I Muvrini as they avidly follow the newspaper reports detailing their latest conquests. And when the groups are playing away, it is the traditional a cappella polyphonic songs that invariably leave the opposition standing and that carry away the prizes.

\section{Unspoken bargains}

I have alluded above to the misconceptions that those we study might entertain regarding our role and purpose in their midst. In my own case, I quickly became aware of a number of ways in which different groups of people with whom I came into contact thought that my interest might serve to benefit their own cause. Even though these various expectations might not correspond to the way in which either I or the research bodies who partially fund my work would see my role, they impinge on me nonetheless. In some cases, they may have been conceived of as part of a bargain struck between us, a statement of how I could pay something back in return for what I had been given. Certainly they will colour both the way in which any text I produce is read and also the evaluation of the success of the enterprise as a whole, which in turn might have repercussions on the way in which future researchers are received.

In a climate where the contemporary "groups" are accustomed to being regularly eulogised in media reports which naturally serve to inflate the sense of importance of individual artists whilst at the same time reinforcing a general popular discourse about Corsican music, my role as writer often seemed to be confused with that of benign journalist who might aid the advancement of aspiring artists by giving them "good publicity". ${ }^{12}$ Others of a more philosophical bent, aware of how easily their own insular concerns could become incestuous, looked to me for a kind of

\footnotetext{
${ }^{11}$ For a discussion of the terms in which musicians formulate their own relationship to the tradition and the ways in which today's groups negotiate a path between the traditional and the contemporary in their own compositions, see Bithell, 2001.
} 
cultural diagnosis, based on my privileged vantage point both as a professional with valuable knowledge and experience of how things operate elsewhere (including what mistakes might have been made and how certain challenges might have been met) and as a relatively dispassionate outsider. "How does it look to you, from the outside?" they would ask as we earnestly debated some aspect of recent musical activity. Thus while some would question my ability to say anything remotely meaningful about their culture - one that I had not grown up in - or would perhaps prefer that I didn't, others appeared almost recklessly keen to put their entire musical fate in my hands. "We need someone to tell us what is valuable and what is not," they might say, "to tell us what we should be doing, which direction we should take next." Some felt that it would be easier for me to write about certain contentious issues precisely because I stood outside the various "factions". I was entrusted with things that, in the opinions of my informants, needed to be said but could not be said by those directly concerned: often there was an urgent feeling that someone must speak out and it could be me. Much as I might sympathise privately with some of the sentiments expressed, this left me in the uncomfortable and onerous position of being charged with the mission of being a mouthpiece for the "truth" and came into obvious conflict with my own post-colonialist scruples.

My ambivalence was reinforced by the knowledge that in some quarters anything which could remotely be construed as criticism would be very badly received. Despite my recourse to the now familiar polyphonic trope, ${ }^{13}$ I was only too aware of the danger of appearing to cast doubt on an individual's professional integrity, knowing that they had built a career or self-image on a certain way of representing some aspect of their culture, and knowing equally that there were others who judged their position to be questionable and potentially damaging to other more modest endeavours. Moreover, in any situation we have to be aware that our data might all too easily be used by the "wrong" side. Any portrayal in our texts that could be interpreted by someone, somewhere, in a negative light might have a very real impact in terms of funding allocations, for example. McDonald has described how the furore which greeted the appearance of her thesis on language

\footnotetext{
12 It is interesting to note that, during my most recent fieldwork trip when I was chasing certain details via archives and other institutions whose staff sometimes made further enquiries on my behalf, I was repeatedly introduced as a journalist.

${ }^{13}$ Given that polyphonic singing was a central focus of my research, the metaphor stood a good chance of being understood, as both method and structure but also as ideology, by some, at least, of my Corsican readers. Indeed, in the case of the more globally articulate players a preoccupation with polyphony in the musical sense had led them straight into the metaphorical post-modern usage.
} 
and education in Brittany (1982) turned her into a "political football" and led to the copy deposited at the Bodleian Library in Oxford being made unavailable for loan after an unwelcome interest had been shown in it by the French government (1987:136). We might equally be paraded as a sort of mascot by the "right" side who use our work in a way that implicates us inappropriately or unintentionally. Babiracki has described how leaders of local political parties and tribal youth leaders in India now quote from her dissertation "to support and validate their struggle for cultural identity and autonomy" (1997:124-5). It is precisely because some of those we work with already foresee the potential for our findings to be used in a way that might work against their own interests that they may have reservations about the extent to which they are happy to collaborate with us.

\section{Playing field or minefield?}

Accounts of the type included in When they read what we write inevitably took on a somewhat alarming note in the context of the political milieu in which I was operating. Without wishing to add to the already regrettable over-problematisation of Corsica or to cast my mission in a particularly heroic light, it has to be said that the climate on the island in the mid-1990s was somewhat volatile - a circumstance of which I had been blissfully unaware when I first fell in love with the music.

It will perhaps be useful at this point to refer briefly to a number of factors which formed the backdrop to my encounter with Corsica itself as my understanding deepened. Working in the Mediterranean region, it is impossible to ignore the "honour and shame" trope which, following Peristiany (1966), was to establish itself as an almost permanent feature of analyses of Mediterranean communities and has proved remarkably tenacious and even self-perpetuating as local people have internalised the characteristics assigned to them by their ethnographers. ${ }^{14}$ Corsica itself counted among those places where the cult of the vendetta - a prime site for the articulation of issues of honour and shame - was particularly deeply embedded. While the vendetta in its "classic" form is now a thing of the past, aspects of the code of silence which accompanied it still linger. In latter-day Corsica, it has been

\footnotetext{
${ }^{14}$ For a survey of anthropological work in the Mediterranean up to the mid 1970s, structured around detailed analysis of the issues and paradigms informing commentaries on the region, see Davis, 1977. For an example of a monograph focusing on questions of male identity in the Mediterranean and the ways in which notions of honour can be seen to permeate almost every aspect of daily life, see Herzfeld, 1985. For a recent plea for the laying to rest of the honour and shame obsession, see Magrini, 2002.
} 
observed, feuds between extended families have been replaced by disputes not only between nationalists and state but also by rifts between and within insular factions themselves. At the same time, the more old-fashioned, internal brand of politics now sits alongside the more contemporary and intercultural politics of minorities and militancy, each, in its own way, contributing to the need for a certain vigilance.

The cultural revival set in motion in the 1970s in which many of today's musicians have played a leading role had its roots - in part, at least - in the nationalist movement, with many of those involved conceiving of themselves as "cultural militants" and being referred to in the press as "soldier-singers". As such they were not immune from imprisonment for their involvement with the clandestine paramilitary FLNC (Front de Libération Nationale de la Corse), and performing at benefits for political prisoners and their families was, in the 1970s and early 1980s, more or less de rigueur. Shared political causes also brought Corsican musicians into contact (whether direct or ideological) with others involved in their own struggles, most notably in Brittany, the Pays Basque, Northern Ireland and Chile. Thus while my understanding of the culture with which I was engaging was informed to some extent by accounts of other Mediterranean societies, it came to be increasingly influenced by accounts of life in other "fringe" areas of Europe which had an active militant population and where questions of identity were particularly complex and hotly debated. The relationship of the French state to its own linguistic minorities being especially pertinent, McDonald's experiences in Brittany gave pause for reflection.

At the time of my extended stay in Corsica (1994-95), many islanders had an ominous sense of a fuse waiting to be lit. Recent interventions in the island's affairs by the French state machinery had more often than not ended in disaster or, at best, disappointment. There were occasional bombings and shootings (sometimes "claimed" or "signed" by one or other of the nationalist factions, sometimes not). There were marked "reactions" when I said which village I was staying in at one point (it was home to the family of a young nationalist who now counted among the disappeared): people would look at me quizzically, wondering how much I knew. Under such circumstances, the realisation of the extent to which musical activity on the island was almost inextricably bound up with politics (to the extent that it was almost impossible to discuss music independently of politics) lent my chosen focus a certain precariousness, over and above the more catholic sensitivities engendered by the representation debate. One of the first questions in any new encounter was 
almost invariably: "Who else have you spoken to so far? Where else have you been?" To some extent, my response would allow my interlocutor to assess the likely nature of my present understanding, but it might also serve to make him or her adopt a more relaxed or, conversely, a more guarded attitude towards me. Not being aware of suspected motives and past rifts, it would have been easy to foul the pitch by mentioning the wrong names. The intense nature of the political climate also introduced a heightened need for me to site myself and to explain my presence in Corsica. People constantly told me that I had courage. At first I wasn't fully aware of what they might be alluding to - the fact of my operating as a lone female, perhaps? but such comments occasionally took on a more ominous edge. I was advised by a journalist on one occasion to be "upfront" when recording, not to appear in any way secretive or undercover. ${ }^{15}$

Luckily, there were a number of factors in my favour, each of which contributed in its own way to vouching for my integrity and good intentions. My student status and the assurance that my work was "for the university" were important: some singers, with previous experiences of having been badly "used" by film companies, needed reassurance that I was not going to put my recordings to any commercial use. My Celtic status put me on the right side of the colonialist divide and also brought with it an assumption of sympathy with the Corsican cause. ${ }^{16}$ Being female afforded me a certain immunity and, in some situations, a quasiinvisibility, while having children with me on occasion undoubtedly rendered me more human, responsible and potentially deserving of protection. ${ }^{17}$ (I hasten to add that my fieldwork did in fact proceed perfectly amicably: any apprehension I may have felt was largely induced by my reading of the negative consequences suffered by other fieldworkers elsewhere rather than by any untoward experience of my own.

\footnotetext{
15 The situation in Corsica is, of course, far removed both from the official censorship of fieldworkers under the Soviet regime (see e.g. Dragadze, 1987, and Noll, 1997) and from such local attitudes towards the censorship of information as challenged Dresch in his research in Yemen (Dresch, 2000).

${ }^{16}$ I was in fact able to make useful contributions to informal debates on language issues from the perspective of my own experience of living in an officially bilingual society. For further comment on the significance of my Celtic identity for my work in Corsica, see Bithell, forthcoming. (See also McKechnie, 1993.)
} 


\section{The fieldworker observed}

In some respects it is perhaps difficult to countenance fieldwork as having a life independent of ethnography since fieldwork that is not written about remains inconsequential and invisible to a scholarly readership back home. But even if we never write a single word, our presence in the field will by no means have gone unremarked by those among whom we have lived and worked. Moreover, even if our published work does reach our "field", the fact remains that only a very small proportion of our erstwhile "informants" are likely to read it: for the rest, what we leave behind will exist primarily in the trail of our direct encounters.

Certainly our very presence has a potential impact on how events are organised and represented, and can in some cases lead to modifications, albeit minor ones, in the unfolding of events as our companions either attempt to accommodate us or respond personally to our presence. ${ }^{18}$ In the early stages of my own fieldwork I took pains to attend the kinds of larger-scale, public events (such as the summer mountain fairs which have evolved from the old shepherds' fairs) which would be unaffected by my presence and in which I could more easily merge into the crowd. This approach was certainly facilitated by the fact that I was operating with the whole island as my field, rather than living day-to-day in a small restricted community; it also ensured that I retained - for a while, at least - a certain anonymity which allowed me to move around freely. Yet even so my presence did not pass unnoted - particularly in places where even a passing tourist was a rare occurrence or in situations which saw me lurking around the normally male territory of the bar and it would have been naive of me to think that people were simply carrying on as though I were invisible.

Barz proposes that "the performance of field research is one of the most meaningful processes engaged by ethnomusicologists to define themselves" (1997:45). It is also the activity by which we are defined by those we work among. In the field, we are also being observed, possibly as the sole representative to date of

\footnotetext{
${ }^{17}$ Pitt-Rivers suggests that children can be a huge advantage in fieldwork, in part because "they are guaranteed the status of innocence to which all fieldworkers should aspire" (1992:141-2).

${ }^{18}$ Many readers will no doubt be familiar with a Gary Larson cartoon which circulated some years ago, in which a group of "natives", on receiving the tip-off that an anthropologist is on the way, rush to hide all traces of their pseudo-modern lifestyle and hastily discard their western dress in favour of more "primitive" garb.
} 
another species. Unwittingly, we are helping those who observe us to build up an impression of the creature's habitat, behaviour patterns, and so on. ${ }^{19}$

Many of the semi-professional singers I encountered in Corsica had already formed an impression of the species "ethnomusicologist" and it was clear that it was not always an entirely favourable one. Aspects of why this might be so became apparent when some comment was made that set me apart from the species as a whole. I acquired a certain reputation, for example, for having "an ear" and learnt that, contrary to what might be expected, this was not necessarily an inbuilt feature of every so-called ethnomusicologist. ${ }^{20}$ At a broader level, many were sceptical about the value of academic analysis with its tendency to categorise or evaluate trends that, from their perspective, were a more or less organic part of real people's lives and that happened for reasons of their own (or for no ostensible reason at all). They were equally impatient of any challenge to their right to do as they liked with their own heritage.

I do not propose to descend at this point, however, into a simple recitation of personal anecdotes, but rather to structure my discussion around a review of what it is that most distinguishes our activities as ethnomusicologists in the field and how these activities might in themselves impact on people and events. In common with our cousins in the social sciences, we engage in fieldwork primarily as a means of collecting data, not only in terms of facts and figures but also in the form of the results of our own observations and, most recently, our direct participation. To this end we are inclined to introduce ourselves to a whole range of people with whom we would not normally associate, to infiltrate events we have no natural right to be seen at, and to ask an inordinate number of questions along the way. We document our findings more or less obtrusively by means of sound recording equipment, cameras and notebooks. Of these, it is perhaps the notebook above all else that sets us apart from those we work with. ${ }^{21}$ Others present may have a walkman or video recorder, tourists take plenty of photographs, but the dedicated researcher is the only one with a notebook and people may rightly wonder what exactly it is that we are so keen to

\footnotetext{
${ }^{19}$ British readers may recall the two-part Horizon documentary, The Musical Mariner, which followed David Fanshawe in his expedition around various Pacific islands collecting materials for his composition Pacific Odyssey and be able to bring to mind the scene where his bedroom doorway is filled by a throng of "native" faces keenly observing every detail of his going-to-bed ritual.

${ }^{20}$ I once arrived to interview a group of people I had never met before to find that I had been preceded by my reputation as "the Welsh girl with the ear".

${ }^{21}$ Barz (1997) has commented on his symbiotic and, in retrospect, obtrusive attachment to his notebook whilst in the field.
} 
get down on paper, and why. If they are informants, are we perhaps to become informers?

The aspect of my own fieldwork behaviour which attracted the most comment was without any doubt my propensity in certain kinds of situations to make notes. Even companions who had grown used to my presence to the point of being disappointed if I failed to show up at some event or gathering they thought I should be interested in would sometimes be thrown off balance when I took out my notebook. The act of writing drew attention at a different level: it marked me out as an outsider with different reasons for being there. The notes seemed to suggest some future and possibly suspect use - certainly one outside their control - to which my observations might be put. They were an indication that the present encounter was not self-contained. The impact made by my note-taking and the extent to which this activity formed a crucial part of my identity for some of those I had worked among was brought home to me during a recent visit to the island when I chanced upon a group of chjam' é rispondi ${ }^{22}$ singers whom I had last seen six years previously and was immediately greeted by one of their number as "the one who used to make notes". ${ }^{23}$ This also reminded me of an earlier debate where one of the poets had brought me into the exchange itself, singing: "Caroline has taken out her notebook now. What does she write in it?"

\section{Field recordings, reconstructions and revivals}

The promotion of participant-observation (in preference to the "armchair" approach) together with the move towards a concern with the particular as opposed to the paradigmatic, via informants' own words as opposed to the generalised pronouncements of an all-seeing all-knowing ethnographer, naturally led to a greater impact of the researcher in the field. These trends also went hand-in-hand with more systematic use of the phonograph as a vital tool for the faithful recording of informants' utterances (Brady, 1999:65-66). A central concern in ethnomusicological research since that time has been the making of musical recordings which are then brought home for analysis. These recordings represent an important and eminently

\footnotetext{
${ }^{22}$ A sung debate or poetic joust in which any number of poet-singers alternate extemporised stanzas.

${ }^{23}$ It was subsequently explained that a "Spanish girl" had been going around doing research after me, but she didn't make notes. In reality, I resorted to making notes in company only on those occasions when there was no other way of recording vital data, as in the case of lengthy stretches of chjam'é
} 
tangible product of our activities in the field which, in terms of the way in which they are later used and in terms of what they represent, distinguish our discipline from the social sciences as a whole. In the early days of recording technology, the central concern was for preservation - essentially in archives in the researcher's home country, albeit with the notion that the recordings might one day be of use to subsequent generations in the host culture itself. ${ }^{24}$ The impact of the recordings themselves, however, is an area to which greater attention might fruitfully be paid.

Recordings of music in the field might be seen as having a double impact, the first associated with the act of making them and the second with their potential later use. The act of recording is in itself an intrusion and a "taking" par excellence. Early pioneers armed with an Edison machine found their mission hampered by numerous complexities resulting from the fear on the part of the guardians of the materials they sought to record that the apparatus (often anthropomorphised) would steal not only their songs but also the soul, identity and life-force of themselves and their people. The psychological strain on informants who agreed to collaborate often far outweighed the demands of simply singing into an unfamiliar machine in an artificial setting. There are chilling accounts aplenty of the fate met by those seen to have betrayed their people by divulging sacred or secret material and the risk of collaboration was certainly increased by the use of the phonograph since "the recorded cylinder was irrefutable evidence that such illicit cooperation had taken place" (Brady, 1999:104). $^{25}$

The point of reference as far as my own recording activity in Corsica was concerned was more often than not that of some quasi-mythical Continental film crew apparently notorious for its unscrupulous dealings. By the time I first arrived on the island, Corsica was by no means virgin territory as far as recording activity was concerned - a factor which in many ways minimised the impact of my own recording but occasionally threw up new obstacles. Félix Quilici, Wolfgang Laade and Markus Römer had each made substantial collections of field recordings

rispondi when I wanted to keep track of the order of the singers at the same same as recording them and was not sure that I would be able to identify all the voices at a later date.

24 Frances Densmore, for example, wrote in her "Open Letter to the Indian Nations" in the early 1940s: "Some day your young men will grow up and be glad that you gave me these songs to keep for you."

${ }^{25}$ One of the reasons given for informants elsewhere welcoming the "invasion" of the phonograph is revealing for the light it sheds on the demands formerly made of singers and other folk artists: Brady (:111) alludes to frequent reports of the "simple gratitude [on the part of informants] for a machine that obviated the performance of songs and tales over and over to a collector attempting to take a 
spanning a period from the late 1940s to the 1970s; a more modest collection had been made by François Flori. By the early 1990s, there were numerous "groups" of Corsican singers not only performing and making commercial recordings of traditional material but also "doing research" among their compatriots, albeit often primarily as a means of unearthing new material to replenish their own repertoire and fuel their next CD. At the same time, a new generation of students at the University at Corte (reopened in the early 1980s) were carrying out more academic research into facets of their own culture, and the new Phonothèque (part of the Musée de la Corse at Corte) had been opened under the direction of Bernardu Pazzoni, himself an active musician and avid collector. ${ }^{26}$

This flowering of indigenous research and recording activity has brought with it a new awareness of copyright and other issues relating to the ownership of the material. In such circumstances local researchers - whether professional or amateur might rightly feel that they should have first refusal on the raw material. I would not wish to take issue with this any more than with the well-established principle that we should not intrude on other people's research "territory". Such a situation can, however, have odd ramifications. I have, for example, found myself in the bizarre position of not being granted permission to make my own recordings of a particular event even though any number of others present, both locals and tourists, might be happily and openly making their own souvenir recordings (both sound and video). In such cases it was my motives for wishing to make the recordings - and, frustratingly, my "professional" approach in terms of actually asking permission that resulted in me being the one who was not allowed to record. In other cases I have been offered the opportunity to buy a locally made recording as opposed to being granted permission to make my own. I suspect that our time-honoured tradition of making field recordings will become increasingly problematic as ever more of the people we work with are alerted to the market potential of their musical capital and acquire the means of making recordings themselves (although it would be misleading to imply that their motives are purely mercenary: in Corsica recordings of religious repertories have been sold in more than one instance as a means of raising funds for the restoration of the church to which the singers belonged).

written transcription". The enhanced fidelity and range of the most up-to-date recording technology allows our impact on the performance event itself to be almost negligible by comparison.

${ }^{26}$ This new research culture has also been encouraged by the availability of grants to cultural associations for renovating or reconstructing parts of the island's heritage. 
I have alluded above to the suggestion that recordings made in the field may one day be of value to a new generation - even if this argument was likely to be proffered by some, at least, of our predecessors primarily as a justification for taking the recordings away. The move towards repatriation - the return of material artefacts (including photographs "taken" in the field) to their place of origin - which has arisen as one of the by-products of anthropology's post-modern crisis has, in some cases, combined with an initiative from inside the culture to produce a situation where historical field recordings have come to play a crucial role in the revival of traditional genres and repertoires by a new generation in search of its roots. Brady (:119-122) describes how, when materials originally recorded on wax cylinders by Alice Fletcher and Francis La Fesch in the late 19th and early 20th centuries and housed ever since in the Library of Congress were returned to the Omaha in the mid 1980s, this led to some of the old songs being reincorporated into the powwow. Brady's description of experiencing the songs that she had previously only heard "thinly rendered on wax" now, on the occasion of her own attendance at the 1985 powwow, "shake the air and throb the ground beneath my feet" (:120) evokes the very dynamic and tangible impact of the repatriated material - one which, moreover, contrasts sharply with the impact of the initial recording endeavours.

Corsica, too, offers a wealth of examples of the way in which neglected or partially forgotten repertoires, often specific to a very restricted locality, have been revived or reconstituted with the help of an old recording that has recently been either rediscovered by chance or made available to a wider local audience for the first time. In some cases, parts of the repertoire have been relearnt directly from the recordings; in other cases the recordings - often themselves lacunary and of a poor quality - have served primarily to stimulate the memories of those who had once been familiar with the material as listeners, even if they had not actually been involved in its performance themselves.

Of the field recording collections mentioned above, it is that of Félix Quilici that was to play the most decisive part in the unfolding of Corsica's more recent musical history. In the words of Nicole Casalonga: “The impact of Quilici was truly a determining factor. ... It would be impossible to talk about Corsican song without referring to the work of Félix Quilici" (interview 2002). Quilici (d.1980) was himself a native of Corsica who, in the course of a distinguished career as solo viola with the Orchestre National de la Radiodiffusion (later the Orchestre National de France), was engaged to take part in a series of collecting missions to the island: the first (1948) on 
behalf of the Musée National des Arts et Traditions Populaires (MNATP, Paris), the second (1949) under the auspices of Radiodiffusion Française, and the third (1960) for the Centre National des Recherches Scientifiques (CNRS). On his retirement he was able to devote himself more fully to the business of musical analysis and it was at this point that he became embroiled in a bitter dispute with the then director of the MNATP on finding that he was now denied access to some of the recordings that he himself had made. At the same time, in the climate of the cultural riacquistu which accompanied the nationalist fervour of the 1970s, it was becoming a source of increasing frustration and resentment that, while a number of repertoires which had since fallen into disuse had been "saved" in the recordings, the heirs to those repertoires did not have access to them. Indeed, for the group Canta u Populu Corsu and others, the Quilici recordings were central to their mission to revive and redisseminate the musical patrimony. ${ }^{27}$ Consequently Quilici soon had the support of a number of the younger cultural activists, together with representatives of the regional cultural institutions, who began to demand that a copy of the whole collection should be returned to Corsica. Considerable pressure was exerted both via the media and via representations to influential politicians in what Nicole Casalonga describes as "a veritable battle ... a terrible battle" (interview 2002). When a copy of the MNATP collection was finally recuperated by the Direction Régionale des Affaires Culturelles (DRAC), the recordings were made available for consultation by anyone who wished to listen to them. The restoration of this material to its place of origin was not only a political triumph but also served to provide a valuable and exhaustive source of additional material which could be relearnt with the help of the cassettes and added to the repertoires of the groups by means of whom it was then redisseminated. A newspaper headline at the time read: "The affair of the Musée des Traditions Populaires: the excellent first record made by 'Canta $\mathrm{u}$ populu corsu' explains and justifies the steps taken to recover the Corsican sound archives" (cf. de Zerbi et al, 1993:94). A few years later, in 1982, the DRAC collaborated with the Phonothèque Nationale (Paris) in the production of a 3-disc "coffret" featuring a selection from the "fonds Quilici" (Musique corse de tradition orale, 1982) and Noel Pinzutti, then the DRAC's director, arranged for complimentary copies to be given to the many musicians and cultural groups actively involved in the riacquistu - an

\footnotetext{
27 Canta (still active) was the seminal "groupe culturel" or "groupe engagé" of the 1970s. For a summary of the group's role in relation to the nationalist struggle, see Bithell, forthcoming. For an exhaustive and beautifully illustrated account of the group's history, see de Zerbi et al, 1993.
} 
important dimension of the DRAC's involvement, as Pinzutti stresses, being that they did not want the discs to be a purely commercial product (p.c. 2002).

The riches which the recordings yielded even exceeded expectations. Many of those involved speak about how it was not simply a matter of rediscovering lost songs or melodies, but also sonorities, timbres, modalities. The recordings were seen to restore a link with the past, to mend the chain of continuity; by bringing this material back into circulation, Canta was able to "speak to people's memory". More than a simple question of music, this was seen as "a sociological phenomenon" (François Buteau, interview, 2002). Listening to those voices from the past also inspired a reflection on the social context of the music (Nicole Casalonga, interview, 2002): what was life like for these people? in what circumstances did they sing the songs? did they always sing them in the same way? what does it mean to sing the same songs in a different age? the majority of the recordings featured men's voices what about the women? The recordings also stimulated town-dwelling young people to seek out older traditional singers still practising their precarious art in remote villages and some of these singers were themselves revitalised by the new interest shown in them.

Another group who drew on items from the Quilici recordings for their own performance and recording repertory was A Cumpagnia (performing arm of the association E Voce di u Cumune). Nicole Casalonga tells of how this led to one particular encounter that she will never forget: "I had heard in the collection of the Phonothèque Nationale this very fine lament sung by Anghjula Maria Lecca, 'A Ghjalinella', a lament on the death of a little hen. I found it so beautiful rhythmically, the manner in which she sang it, in fact everything about it - that I learnt it myself. Then, on the occasion of a concert we were giving in Paris, I sang it, and at the end of the concert I saw a woman coming towards me ... with tears in her eyes, and she embraced me and said, 'Madame, you have given me immense pleasure, you sang the song of my mother.'" Delighted and equally moved to learn that Anghjula Maria was still alive and well in Corsica, Casalonga arranged to visit her. She continues: "First of all she told me her whole life story, all about her life as a shepherdess, what she did, the path of her transhumance from the Liamone valley to the Lago di Creno [a lake high up in the Niolu plateau], with her children ... and she sang me 'A Ghjalinella' again ... and after that she sang ... the song that she had improvised for the marriage of one of her sons, and in this improvisation she retraced her whole life as a young shepherdess, as a mother ... evoking her little 
house near the lake and exhorting her children to restore it and to ensure that the roof would never fall in. It was sublime, this poetry was extraordinary. ... For me, this was in a small way the continuity of the work of Félix Quilici. It was because I had heard that song that I had the good fortune to meet this wonderful improviser, Anghjula Maria Lecca." (Interview 2002)

In later years, Laade's field recordings were to serve as an important source for Mighele Raffaelli and Ghjermana de Zerbi's Antulugia di u cantu nustrale (three of the twelve volumes planned have been published at the time of writing). Raffaelli (interview 1995) explains that Laade's collection was particularly valuable in that it included a substantial amount of material recorded in villages in the south of the island (Quilici had concentrated more on the north). ${ }^{28}$ Römer's impact has been felt more in the realm of religious music practices. In the 1970s, he successfully made use of playback techniques as a means of reconstituting material for two or three voices where only a single singer remained who was nevertheless able to sing the different parts (cf. Römer, 1983). In one village where this procedure was adopted, the singer had asked to be given a gramophone record of the reconstructed material from the requiem mass (with each of the voices sung by himself) so that it could be played at his own funeral (p.c. 1995). Other recordings made by both Römer and Laade have since been requested by new équipes of singers in the villages concerned who have then worked to reinstate, with their help, traditions which had lain dormant for a generation or more. Römer also offers an example of the way in which a fieldworker's musical expertise can be fed back even more directly, describing how he responded to a request by members of the confraternita in the village of Cardo (which he had adopted as his Corsican base) that he should teach them to sing the Dio vi Salvi Regina ${ }^{29}$ in the characteristic three part polyphonic setting found in other parts of the island (p.c. 2002).

Corsica also presents some noteworthy examples of research initiated by Corsicans themselves having a significant impact in terms of reconstituting repertoires and practices whose chain of transmission had been broken. A case in point is that of the work of members of the association E Voce di u Cumune, in tandem with Annie Goffre of the MNATP, in researching and in some cases

\footnotetext{
${ }^{28}$ A number of these songs are included on the disc $U$ Cantu Prufond $u$ where they are sung by Mighela Cesari with instrumental accompaniment by Raffaelli. Again, individual items from the collection were to lead to unexpected encounters and in particular to the reconstitution of fragmentary song texts.
} 
reconstructing polyphonic mass settings specific to individual villages which had fallen into disuse during the 1930s and 1940s but are now being performed again by groups of local singers and indeed transmitted once more to a younger generation via the oral tradition. ${ }^{30}$ Meanwhile, the attention paid to the polyphonic repertory in general by outside academics certainly has played a large part in fuelling the new burst of polyphonic activity which occurred in the 1990s.

My own contribution in the context of "returning" material has, to date, been modest. One of the most memorable interactions, however, was when I became the intermediary in acquiring from Laade a copy of his CD Corsica: Traditional Songs and Music (1990) - a selection of his field recordings dating from 1958 and 1973 - to pass on as a gift to one of the singers featured on it. When I had first been taken to visit this singer she had been somewhat guarded and had proceeded to tell me how, many years ago, a musicologist had arrived in the small town where she lived and had persuaded her to sing for him. Afterwards some of her friends had admonished her, saying that she should not have given her songs away so freely, and this had subsequently become, it seemed, a cause of some regret. I was never able to establish whether this particular encounter had involved Laade or someone else, but this was how I had come to mention the matter to him and to acquire a copy of his CD on which she did in any case feature. On forwarding the CD on to her, I was astonished to receive in return a warm and effusive letter telling me how moved she had been to meet once more the voice of her youth which she had never expected to hear again before she departed this earth and how it had taken myself, a complete stranger, to come all the way from Wales in order to return her song to her. The prospect of returning individual copies of recordings to all of those we have ever recorded is both daunting and, in many cases, impractical, but in human terms any such gesture is likely to be worth its weight in gold. In some cases we might be returning a person's youth to them; in others we might literally be bringing back the voices of the dead. ${ }^{31}$

\footnotetext{
${ }^{29}$ Anthem to the Virgin Mary which has now become, to all intents and purposes, the national anthem of Corsica.

${ }^{30}$ My researches in this area are ongoing and the results have yet to be published. The joint project undertaken by EVC and Annie Goffre, referred to above, is documented in Centre D'Ethnologie Française A.T.P./E Voce di u Cumune, 1996.

${ }^{31}$ The Musée de la Corse is today striving to adhere to a professional code of ethics in its own handling of recorded material. The boxed set of books produced in conjunction with the 2001 exhibition "Corsica Christiana" includes a CD with a selection of musical examples taken from the various field recording collections held at the museum's own Phonothèque. Complimentary copies of this $C D$ were sent to the relatives of all the singers featured.
} 
The recuperation of other records in the form of translations of theses and monographs based on research in Corsica is now anticipated. Not only do these accounts contain the ethnographer's own analyses and interpretations: more importantly for local readers, they also include vital historical data in the form of documentation of musical activity in particular villages in past generations and citations from interviews with singers and others long since dead. That the descendants of these "informants" should not have access to their words because they have only been published in a foreign language is indeed anomalous and hardly satisfactory.

\section{Participation, performance and personal interactions in the field}

Kisliuk has insisted on the impracticality and indeed the impossibility of separating field experience from ethnography when the focus of our ethnography is the act of performance, arguing that "the challenge to ethnomusicologists is to create ethnographies of musical performance that are fully experiential" (1997:41). Certainly the essential focus of our research - music-making - offers a capital opportunity for real participation and, beyond that, for becoming actors in our own object of study in the most direct way. In my own case, not only did I contribute Welsh songs when called upon to do so; I attended numerous classes and workshops where I learnt about the way in which Corsican songs and singing style were transmitted while also learning to sing some of the songs myself; and finally I graduated to singing the occasional paghjella around the table together with my Corsican friends.

One of the most curious experiences, however, has undoubtedly been that of finding myself featuring - as an implied presence rather than as an actual voice - in my own field recordings. On occasions when I was included in a group of singers at a fair (as opposed to simply being on the edge of the group as an anonymous observer), my tapes tended to feature a disproportionate number of serenades which were, I was told, sung to please me: often they were chosen because the text included some apposite reference such as the colour of my hair or eyes. Sometimes stanzas were improvised especially for me. I alluded above to an instance where my notebook became a cause for comment in the course of a chjam' è rispondi session. On another particularly memorable occasion, my presence at a sheep-shearing provided the main theme for an extended bout of chjam' è rispondi in which one singer teased his friend and interlocutor along the lines of "now that the girl with the chestnut hair 
is here, you haven't got eyes for anyone else", ending each of his stanzas by conjuring up a new image of what the unfortunate man's wife was going to do to him when he got home. (The formulaic construction of the final couplet allowed for the substitution of a new weapon and a new location each time, which made the whole exchange start to resemble a game of Cluedo, with successive images of the aggrieved wife lying in wait with a pistol in the kitchen, with a dagger in the bedroom, and so on.) All of this was a cause of huge hilarity to the crowd of (male) onlookers, one of whom would occasionally glance timidly in my direction, saying in worried tones, "she doesn't understand, does she?" I did my best to affect the benign smile of the innocent as I kept the tape rolling. Later, over a prolonged lunch, the singing continued and the wine flowed freely and once more I - one of only three younger women sitting at the table with thirty or so men in festive mood - became the pretext for songs of an increasingly ribald nature. Finally two or three older women came out of the kitchen, clapped their hands sharply, and packed the men off outside to play football. "There comes a point", they explained for my benefit, "when it is not good to encourage them any further."

As Cooley points out (1997:11), fieldwork is no longer simply about "collecting data to support goals external to the field experience". We no longer view our informants simply as sources of information: they become our friends and we become - if only temporarily - a real presence in their lives. In an attempt to kick over the more exploitative traces of some, at least, of those who have been there before us, we might actively strive to establish a greater sense of "community" with those we study. But the new emphasis on "understanding" and on human relationships which has informed the most recent phase of our discipline (Titon 1997:92) has brought new dilemmas of its own in the form of what Spindler, writing in 1970, termed "the excruciating ethical problems of becoming friends with people in order to observe them at close and meaningful range" (:vii). Those we work with are surely to be forgiven if they do not understand "the method of participant-observation ..., whereby an outsider becomes an insider, a stranger becomes a friend, and confidences become data" (Brettell, 1993:11) - a stark formulation which makes such an approach seem unforgivably cold-blooded and not something that I can feel proud to be part of.

Kisliuk, meanwhile, has commented that "the deeper our commitment in the field, the more our life stories intersect with our 'subject's'" (1997:23). Added to the thorny question of the extent to which we might be exploiting such friendships in 
terms of the informally acquired material that later finds its way into our texts is that of how we maintain friendships after leaving the field. Do our erstwhile friends feel betrayed when we suddenly leave? Do they understand why we have to leave? Might they later feel that friendships with foreigners are not really worth investing in? Or will they confidently await our return? Or even be happy to accept our transitory relationship as a sort of holiday romance?

Hastrup speaks of the inherent violence in "the drama of fieldwork", referring to her own "pain" resulting "from having been fieldworked upon" and concluding that "the ethnographer cannot avoid leaving her informants at a loss" (1992:122-4). Part of the intensity of the fieldwork experience for the researcher results from the need to make what are often drastic changes in lifestyle and outlook. This is not ordinarily the case for those who come under observation as they simply go about their normal day-to-day lives into which we have intruded uninvited.

\section{Conclusions}

I certainly experienced, in the course of my own fieldwork, the "self-expansion", enlarged "range of perceptions and sensitivities", and "changes in personal values" identified by Spindler (1970:v). I knew very little about Corsica before I went there. It all happened rather quickly. I heard some singing at a festival and I was enchanted. One of the singers spoke about a recent revival and I was intrigued. I looked in vain for information on Corsican music in English and I was onto something. What I did glean about the island indicated that it was culturally quite remote from home, yet it was near enough, geographically speaking, for me to be able to get in my car and drive there. Soon I was on a ferry crossing the Mediterranean. Not surprisingly, I fell in love with the place and grew fond of many of its people. When I left the island in 1995 after my main period of residence there, I left behind a trunk with a set of camping gear, symbolic of a home and of my intention to return. For months, I was still in Corsica in my dreams. For my children, life on the island had become a yardstick by which they measured anew the world of home; their futures have unfolded in directions which I would not have anticipated if they had simply stayed at home.

My gain, then, is obvious. But what did my presence do for them? It is, perhaps, premature to ask how exactly my Corsican friends and colleagues might benefit from the results of my work. Certainly I can aid their cause in a general way 
by making Corsican music more widely known to an anglophone readership and by helping it achieve a firmer footing on the global musical map. I can draw attention to the wealth of recent output in terms of discs which are difficult to simply happen upon outside of France, while at the same time helping keep the balance straight by turning the spotlight equally on those still practising their art as part of a traditional lifestyle which, after all, is not yet dead. In the case of those with whom I have enjoyed the most prolonged contact, I like to think that we have shared a genuine mutual passion and engaged in a debate that has been meaningful to both sides and offered a constructive space for reflection and consolidation. In some cases, my outsider's ear has also given them the opportunity to express their misgivings, disappointments and frustrations, perhaps allowing them to tell a part of their story which they did not choose to tell to those they feared might turn it to their own advantage. How acceptable the detail of my written accounts will be to any particular Corsican remains to be seen. I hope they will concede that there is a place for cultural commentators whose pronouncements are not seen as the definitive judgement of an expert endowed with a quasi-divine authority, but as offering a more modest return in the form of a perspective which might resonate in some ways with some people.

It matters greatly how we operate in the field and how we communicate our "findings" but, I have argued, it is hardly possible to foresee all possible outcomes or forestall all possible accidents. Neither we nor our fieldwork collaborators can know how things will turn out in the long run. Irritations and intrusions now may be things to be thankful for later. The ground shifts, our impact is not contained within a single dimension; it is multifaceted and changes over time. (And here I would make a case, too, for future revisiting of the field as part of our responsibilities. Having started the ball rolling, we surely need to keep apace of the changes of direction? Having given our collaborators a voice, how can we silence them again? Who are we to decide that the story has ended? Revisiting offers the opportunity to fill in further pieces of the jigsaw, rather than leaving our readers to assume that the rest is all infinite and eventless blue sky.)

We should be careful and alert, certainly, but aware also of the danger of becoming too introspective, too preoccupied with our own fate, and too inclined to focus on the negative. We also have to be prepared to take a longer view. Despite the place of honour reserved for Quilici in Corsica today, he was by no means immune from criticism in his own time. Some have suspected his motives in the usual ways 
(what did he stand to gain?). In the seventies there were those who questioned his political allegiances. There are those who would still take him to task for overlooking their village and its own unique repertory (now fallen between the cracks of memory) in favour of villages like Rusiu which benefited from special promotion (the impact of what we don't record). Yet without his pioneering work, it is questionable whether a succession of Corsican groups would have carried off the prize for "traditional music" in the French Victoires de la Musique in recent years. Without the systematic recording of Römer and the reconstruction work of those who followed in his footsteps (such as the Goffre/EVC team), the villages in which one call still hear unique polyphonic settings of the Latin mass would undoubtedly be fewer. One might also wonder how large sections of Corsican youth would be spending their time if they were not so addicted to polyphonic singing.

In the face of the enormity of the ground that has been gained, my occasional fretting about the possible negative impact of aspects of my own work pales into more realistic proportions. The risks come with the job. The best we can do is to ensure that new recruits are made aware of these risks sooner rather than later - and it is here that the reflexive turn has been of such value. Reading accounts of the challenges and dilemmas faced by others in the field has been a vital part of my own education and has served as reassurance as well as warning. At the same time, while a shift away from a tendency to complain of the discomforts of life in the field, the non-compliance of one's subjects, and so on, towards a searching of one's own soul has been in many ways a healthy one, the time has doubtless come for the reflexive turn itself to move on. I have attempted in this article to explore the middle ground where my world view has met that of my Corsican collaborators, to set out the different perceptions, expectations and hopes that each of us has brought to the none too virgin turf of our encounter, and to explore the moves and countermoves that we each might make. I don't expect to win, but I hope I have played hard and honourably.

However my own modest efforts may be judged, I can only plead my best intentions. Above all else I have wanted to pay homage to the island, to the efforts of the various groups and individuals who have worked for the survival of their cultural heritage, to their resilience in the face of undeserved and seemingly unrelenting oppression, and to their earnest engagement with such questions as "where do we go from here?", "what future do we want to create for ourselves?", "what story should we be telling?" Meanwhile, their history will continue to be made. 
I hope they will know that, in my heart, I will always be standing there on the sidelines, cheering for them all the way.

\section{References}

Averill, Gage (1997) A day for the hunter, a day for the prey: popular music and power in Haiti. Chicago and London: University of Chicago Press.

Babiracki, Carol M. (1997) “What's the difference? Reflections on gender and research in village India." In Barz, Gregory F., and Cooley, Timothy J. (eds), Shadows in the field: new perspectives for fieldwork in ethnomusicology, pp. 121-136. Oxford: Oxford University Press.

Barz, Gregory F., and Cooley, Timothy J. (1997) Shadows in the field: new perspectives for fieldwork in ethnomusicology. Oxford: Oxford University Press.

Barz, Gregory F. (1997) "Confronting the field(note) in and out of the field: music, voices, texts, and experiences in dialogue." In Barz, Gregory F., and Cooley, Timothy J. (eds), Shadows in the field: new perspectives for fieldwork in ethnomusicology, pp. 45-62. Oxford: Oxford University Press.

Bithell, Caroline (1996) "Polyphonic voices: national identity, world music and the recording of traditional music in Corsica." British Journal of Ethnomusicology 5:39-66.

(1997) “Issues of Identity and Transformation in the Revival of Traditional Song in 20th Century Corsica." Unpublished PhD thesis, University of Wales, Bangor.

(2001) "Telling a tree by its blossom: aspects of the evolution of musical activity in Corsica and the notion of a traditional music of the 21st century." Music and Anthropology 6 <http://www.muspe.unibo.it/period/MA/> (forthcoming) "Shared imaginations: Celtic and Corsican encounters in the soundscape of the soul." In Stokes, Martin \& Bohlman, Philip V. (eds.), Celticisms. Lanham: Scarecrow Press.

Brady, Erika (1999) A spiral way: how the phonograph changed ethnography. Jackson: University Press of Mississippi.

Brettell, Caroline B. (1993) When they read what we write: the politics of ethnography. Westport, Connecticutt: Bergin and Garvey.

Centre d'Ethnologie Française-Musée National des Arts et Traditions Populaires / Associu E Voce di U Cumune (1992) Contributions aux recherches sur le chant 
corse I: polyphonies vocales et orgue. Paris: CEF-MNATP. (Republished (1997) by Éditions Harmattan as Polyphonies corses: l'orgue et la voix.)

Clifford, James, and Marcus, George E. (eds) (1983) Writing culture: the poetics and politics of ethnography. Berkeley: University of California Press.

Clifford, James (1983) "Introduction: partial truths." In Clifford, James, and Marcus, George E. (eds), Writing culture: the poetics and politics of ethnography. Berkeley: University of California Press.

Cooley, Timothy J. (1997) “Casting shadows in the field: an introduction.” In Barz, Gregory F., and Cooley, Timothy J. (eds), Shadows in the field: new perspectives for fieldwork in ethnomusicology, pp. 3-19. Oxford: Oxford University Press.

Davis, John (1977) People of the Mediterranean. London, Henley and Boston: Routledge and Kegan Paul.

de Zerbi, Ghjermana et al (1993) Canta u Populu Corsu. Levie: Éditions Albiana.

Dragadze, Tamara (1987) “Fieldwork at home: the USSR.” In Jackson, Anthony (ed), Anthropology at home, pp. 154-63. London and New York: Tavistock Publications.

Dresch, Paul (2000) “Wilderness of mirrors: truth and vulnerability in Middle Eastern fieldwork." In Dresch, Paul, James, Wendy, and Parkin, David (eds), Anthropologists in a wider world, pp. 109-127. New York and Oxford: Berghahn Books.

Erlmann, Veit (1996) Nightsong: performance, power, and practice in South Africa. Chicago and London: University of Chicago Press.

Gluckman, M. (1967) “Introduction". In Epstein, A.L. (ed), The craft of social anthropology. London: Tavistock Publications.

Hastrup, Kirsten (1992) "Writing ethnography: state of the art." In Okely, Judith \& Callaway, Helen (eds), Anthropology and autobiography. ASA Monographs 29. London and New York: Routledge.

Herzfeld, Michael (1985) The poetics of manhood: contest and identity in a Cretan mountain village. Princeton and Chichester: Princeton University Press.

Jaffe, Alexandra (1993) "Involvement, detachment, and representation on Corsica." In Brettell, Caroline B. (ed), When they read what we write: the politics of ethnography, pp. 51-66. Westport, Connecticutt: Bergin and Garvey.

Kisliuk, Michelle (1997) “(Un)doing fieldwork: sharing songs, sharing lives.” In Barz, Gregory F., and Cooley, Timothy J. (eds), Shadows in the field: new perspectives for fieldwork in ethnomusicology, pp. 23-44. Oxford: Oxford University Press. 
Laade, Wolfgang (1981) Das korsische Volkslied: Ethnographie und Geschichte, Gattungen und Stil (3 vols.). Wiesbaden: Franz Steiner Verlag.

Loizos, Peter (1992) “User-friendly Ethnography?" In Pina-Cabral, Joao de, and Campbell, John (eds), Europe observed, pp. 167-187. Basingstoke and London: MacMillan Press.

Marcus, George E. (1998) Ethnography through thick and thin. Princeton: Princeton University Press.

McDonald, Maryon (1982) "Social aspects of language and education in Brittany." D. Phil thesis, University of Oxford.

(1987) “The politics of fieldwork in Brittany." In Jackson, Anthony (ed), Anthropology at home, pp. 120-138. London: Tavistock Publications.

McKechnie, Rosemary (1993) "Becoming Celtic in Corsica." In Macdonald, Sharon (ed), Inside european identities, pp. 118-145. Oxford: Berg.

Magrini, Tullia (ed) (2002) Music and gender: perspectives from the Mediterranean. Chicago and London: University of Chicago Press.

Meintjes, Louise (1990) "Paul Simon's Graceland, South Africa, and the mediation of musical meaning." Ethnomusicology 34.1:37-73.

Musée de la Corse (2001) Corsica christiana: 2000 ans de christianisme. Collectivité Territoriale de Corse. (Boxed set of catalogues to accompany exhibition.)

Noll, William (1997) "Selecting Partners: questions of personal choice and problems of history in fieldwork and its interpretation." In Barz, Gregory F., and Cooley, Timothy J. (eds), Shadows in the field: new perspectives for fieldwork in ethnomusicology, pp. 163-88. Oxford: Oxford University Press.

Okely, Judith \& Callaway, Helen (eds) (1992) Anthropology and autobiography. ASA Monographs 29. London and New York: Routledge.

Peristiany, J. G. (ed.) (1966) Honour and shame: the values of Mediterranean societies. Chicago: University of Chicago Press.

Pitt-Rivers, Julian (1992) “The personal factors in fieldwork.” In Pina-Cabral, Joao de, and Campbell, John (eds), Europe observed, pp. 133-147. Basingstoke and London: MacMillan Press.

Römer, Markus (1983) Schriftliche und mündliche Traditionen geistlicher Gesänge auf Korsika. Wiesbaden: Franz Steiner Verlag.

Spindler, George D. (ed) (1970) Being an anthropologist: fieldwork in eleven cultures. New York: Holt, Rinehart and Winston, Inc. 
Titon, Jeff Todd (1997) "Knowing fieldwork." In Barz, Gregory F., and Cooley, Timothy J. (eds), Shadows in the field: new perspectives for fieldwork in ethnomusicology, pp. 87-100. Oxford: Oxford University Press.

Watson, C.W. (ed) (1999) Being there: fieldwork in anthropology. London and Sterling: Pluto Press.

\section{Discs cited}

Corsica: traditional songs and music (1990) Jecklin-Disco JD 650-2 (field recordings by Wolfgang Laade, 1958 \& 1973).

Mighela Cesari \& Mighele Raffaelli (1993) U cantu prufondu. Ricordu CDR 088.

Musique corse de tradition orale (1982) Archives Sonores de la Phonothèque Nationale, Paris APN82-1/3 (field recordings by Félix Quilici, 1961-1963).

\section{Interviews cited}

Buteau, François (Cecce): Ajaccio, July 2002

Casalonga, Nicole: Pigna, July 2002

Raffaelli, Mighele: Bastia, March 1995 